\title{
Some Epidemiological Studies on Rice Blast Disease Caused by Pyricularia oryzae
}

\section{Efkan AKÇALI ${ }^{1}$, Şener KURT ${ }^{2}$}

${ }^{1}$ Biyolojik Mücadele Araştırma Enstitüsü, 01321, Adana, Türkiye, ${ }^{2}$ Hatay Mustafa Kemal Üniversitesi, Ziraat Fakültesi, Bitki Koruma Bölümü, 31001, Hatay, Türkiye

${ }^{1}$ https://orcid.org/0000-0002-5486-7502, ${ }^{2}$ https://orcid.org/0000-0003-4545-5968

凹: akcaliefkan@hotmail.com

\section{ABSTRACT}

In this study, the effects of temperature and the duration of leaf wetness on the development of rice blast disease caused by Pyricularia oryzae and the reactions of Edirne and Osmancik-97 rice cultivars were investigated under controlled environmental conditions. Rice cultivars Edirne and Osmancık-97 were inoculated with a conidial suspension $\left(5 \times 10^{5}\right.$ conidia $\left.\mathrm{ml}^{-1}\right)$ of $P$. oryzae and exposed to combinations of five different leaf wetness durations (from 6 to $30 \mathrm{~h}$ ) and four different temperatures $\left(20\right.$ to $\left.32^{\circ} \mathrm{C}\right)$ over the course of infection period. Disease severity on cvs. Edirne and Osmancik-97 increased with increasing temperatures and hours of wetness duration. The highest disease severity was detected on plants exposed to $30 \mathrm{~h}$ leaf wetness duration at $28^{\circ} \mathrm{C}$, while the lowest disease severity values were observed $6 \mathrm{~h}$ leaf wetness duration at $20^{\circ} \mathrm{C}$ temperature. Increased leaf wetness durations significantly increased disease severity at optimal temperature. But, it was observed that the all disease severity values on cv.Osmancık-97 was lower than cv. Edirne at same temperatures and leaf wetness durations. In addition, a new and simple technique was developed to increase the sporulation capacity of the $P$. oryzae to provide enough inoculum quantity in the experiments by this study.
\end{abstract}

\section{Pyricularia oryzae hın Neden Olduğu Çeltik Yanıklık Hastalığı Üzerine Bazı Epidemiyolojik Çalışmalar}

\section{ÖZET}

Bu çalışmada, Pyricularia oryzae'nin neden olduğu çeltik yanıklık hastalığının gelişiminde sıcaklık ve yaprak ıslaklık süresinin etkileri ile Edirne ve Osmancık-97 çeltik çeşitlerinin hastalığa karşı tepkileri kontrollü çevre koşulları altında incelenmiştir. Edirne ve Osmancık97 çeltik çeşitleri $P$. oryzae'nı $\left(5 \times 10^{5}\right.$ conidia $\left.\mathrm{ml}^{-1}\right)$ konidial süspansiyonu ile inokule edilmiş ve enfeksiyon dönemi boyunca dört farklı sıcaklık $\left(20-32^{\circ} \mathrm{C}\right)$ ve beş farklı yaprak islaklık süresi (6 ila 30 saat) kombinasyonuna maruz burakılmıştır. Edirne ve Osmancık-97 çeşitlerinde, hastalık şiddeti artan sıcaklıklar ve yaprak ıslaklık süreleri ile yükselmiştir. En yüksek hastalık şiddeti $28^{\circ} \mathrm{C}$ sıcaklıkta 30 saat yaprak islaklık süresine maruz kalan bitkilerde tespit edilirken, en düşük hastalık şiddeti değerleri $20^{\circ} \mathrm{C}$ sıcaklıkta 6 saat yaprak ıslaklık süresinde saptanmıştır. Yükselen yaprak ıslaklık süreleri, optimum sıcaklıkta hastalık şiddetini önemli ölçüde artırmıştır. Ancak Osmancık-97 çeşidindeki tüm hastalık şiddeti değerlerinin aynı sıcaklık ve yaprak ıslaklık sürelerinde Edirne çeşidinden daha düşük olduğu görülmüştür. Ayrıca, bu çalışma ile denemelerde yeterli inokulum miktarını sağlamak için $P$. oryzae'nin sporlama kapasitesini artıracak yeni ve basit bir teknik geliştirilmiştir.

To Cite : Akçalı E, Kurt Ş 2021. Some Epidemiological Studies on Rice Blast Disease Caused by Pyricularia oryzae. KSU J. Agric Nat 24 (6): 1221-1229. DOI: 10.18016/ksutarimdoga.vi.851241.

\section{INTRODUCTION}

Rice has been considered one of the most significant

\section{Research Article}

$\begin{array}{ll}\text { Article History } & \\ \text { Received } & : 31.12 .2020 \\ \text { Accepted } & : 12.03 .2021\end{array}$

Keywords

Rice blast

Duration of leaf wetness

Temperature

Disease severity

Araştırma Makalesi
Makale Tarihçesi
Geliş Tarihi : 31.12 .2020
Kabul Tarihi : 12.03 .2021
Anahtar Kelimeler
Çeltik yanıklığı
Yaprak ıslaklık süresi
Sıcaklık
Hastalık şiddeti

staple food crops of more than half of the world's population (Nalley et al., 2016). The global rice 
production has reached to 510.1 million tonnes in 2018 and consumption has expanded by 1.1 percent in $2017 / 18$ to 503.9 million tonnes (FAO, 2020). Asian countries supply approximately $90 \%$ of the world rice production. While China has a $27 \%$ share in world production with 208 million tonnes, followed by India with 22\% and Indonesia with 9.7\% (FAO, 2018). Turkey's rice farming has been made in around 120 thousand hectare areas in Marmara, Black Sea, Southeast Anatolia, the Mediterranean and the Aegean regions and rice production was approximately 940 thousand tonnes (TUIK, 2018). The current global human population is predicted to grow by over a third and to reach 9 billion between 2009 and 2050 (Godfray et al., 2010); accordingly, it must increase by $70 \%$ globally cultivated land between 2005 and 2007 and 2050 to reach food request from population development (FAO, 2009). Therefore, any reduction in production will have adverse effects on human food demand.

Rice diseases caused by fungi are considered as the main limiting factor in rice production and cause both qualitative and quantitative losses (Kongcharoen et al., 2020). Rice blast, caused by the heterothallic ascomycete fungus Pyricularia oryzae Cav. (teleomorph: Magnaporthe oryzae) on rice, is one of the most widely disseminated and economically destructive diseases of rice and grass plants in the world (Ou,1985; Asibi et al., 2019) and Turkey (Oran, 1975). Rice blast, the most serious and widespread disease in global rice production, is responsible for approximately $45-50 \%$ of rice yield losses worldwide (Singh et al., 2019; Asibi et al., 2019). It is therefore one of the most important limiting factors in rice production and a serious concern for the combat with global food security. $P$. oryzae species complex that causes blast disease has a broad spectrum of host range and is known to infect almost more than 50 species of the gramineae plants including rice, wheat, and millets (Castroagudín et al., 2016). It has been stated that rice production was affected by the rice blast disease in more than 50 countries around the world, including America and Europe (Sirithunya et al., 2007). Also, rice blast was reported to infect rice resulting in yield loss of about $30-80 \%$ in Southeast Asia, South America and other parts of the world (Ou, 1985; Talbot, 2003; Khush and Jena, 2009). Unless the spraying is made, it may cause yield loss at levels ranging between 60 to $100 \%$ in areas where sensitive varieties of rice are grown (Aravindan et al., 2016).

In the field, the fungus is encountered mainly in the anamorphic state which used to be called Pyricularia oryzae if it infects the rice. Also, Magnaporthe grisea can attack wheat, barley and various wild grasses on which the asexual state is called $P$. grisea (synonym: Pyricularia oryzae). The fungus infects any aerial part at all developmental stages of rice, causing leaf, collar, neck and panicle blast symptoms. Leaf infection reduces the photosynthetic capacity of the plant and can even lead to death of the plant. However, panicle infection that result in yield loss causes great economic damage. Climatic conditions significantly affect the disease establishment, development and severity resulting in large genotype by environment interactions. The majority of field studies about rice blast disease has been conducted in tropical and subtropical environments (Suzuki, 1975; Groth, 2006). Temperature and wetness duration are significant atmospheric parameters influence the relation between fungal plant pathogens and host plants. Temperature generally accelerate biological process and both plant and their pathogens. The wetness duration that a part of plant is subjected to liquid water is an important factor affecting the occurrence and development of disease. Spore germination and appressorium formation require free water. It is both difficult and time consuming for rice breeders to breed for resistance to current strains of blast since blast is a fungus that can evolve and mutate to overcome resistance genes (Zhou et al., 2007). Identifying environmental parameters necessary for the occurrence and development of the disease help to understand the biology and epidemiology of the disease. Integrated management using biofungicides, resistant cultivars, chemical fungicides for foliar spraying and fluxapyroxad for seed application are the most effective tools in management of blast in rice growing areas where conditions are favourable for severe epidemics (Gohel and Chauhan, 2015; Chen et al., 2019; Anonymous, 2020; Kongcharoen et al., 2020).

Management of rice blast through breeding blastresistant varieties had only limited success due to the frequent breakdown of resistance in field conditions (Bonman et al., 1992). Understanding the biology of rice blast disease is therefore of particular significance because it promises to develop new and durable disease control strategies (Skamnioti and Gurr, 2009).

Temperature and leaf wetness are important factors deciding the progress of fungal plant diseases (Diéguez-Uribeondo et al. 2011; Uysal and Kurt 2017), because they play a key role in the infection process, namely conidial germination, appressorium formation, and germ tube elongation. Hence, the interactions between leaf wetness duration and temperature are scientifically important, because they were used to create different forecasting models depending on climate parameters.

The objectives of this study were to assign the effects of temperature and duration of leaf wetness on the progress of rice blast disease caused by $P$. oryzae and reactions of Edirne and Osmancık-97 cultivars against blast disease in controlled environment conditions. Knowledge on the effect of climatic parameters could be utility for making or improving a novel forecasting 
model which uses for estimate of timing of fungicide applications, so rice blast disease could be controlled with true spray timing and decreasing fungicide spray numbers.

\section{MATERIAL and METHOD}

\section{Plant production}

For this purpose, rice seeds cvs. Edirne and Osmancik97 grown commercially in Edirne, Turkey were used in all experiments. The seeds were sown in a mixture $(4: 1$, $\mathrm{v} / \mathrm{v})$ of sterilized soil and peat in a 28 cell plastic growing tray. Before sowing, seeds were treated with tap water during about 3-4 days of room temperature, and transferred into growing trays. Rice plants were cultivated in a climatic chamber set at $26^{\circ} \mathrm{C}$ temperature and $70 \%$ humidity.

\section{Preparation of inoculum}

$P$. oryzae isolate $\mathrm{PC} 1$ was obtained from infected rice plants from Ceyhan district of Adana province of the Mediterranean Region in 2010. This virulent isolate of $P$. oryzae has been chosen to represent the population of Turkey. Isolation of the pathogen from infected leaf tissue of the rice plant was particularly difficult, because of the contamination of other microorganisms and the slow growing and the non-competitive growth characteristics of $P$. oryzae on an artificial growing medium.

The isolation was achieved by suspending rice leaf with symptomatic blast blades by pasting double sided tape to the lids of $9 \mathrm{~cm}$ petri dishes containing water agar. After incubation for $24 \mathrm{~h}$ at $26^{\circ} \mathrm{C}$, conidia released from the conidiophores were collected on the water agar surface. Fungal hyphae were taken from the agar medium and transferred on PDA (potato dextrose agar, Merck, Darmstadt, Germany) supplemented with $50 \mathrm{mg} \mathrm{L}^{-1}$ streptomycin sulphate. The causal agent was identified based on morphological and cultural characteristics. Virulence test was performed by spraying plants with a suspension of $5 \times 10^{5}$ conidia $\mathrm{ml}^{-1}$ using a hand held sprayer to confirm pathogenicity of $P$. oryzae on rice plants. Conidial suspensions were prepared by flooding the surface of the colony with $10 \mathrm{ml}$ of sterile distilled water by gently rubbing the surface with a sterile bent glass rod and filtering the resulting suspension through two layers of cheesecloth. In order to increase conidial density for inoculum concentration desired, the suspension was centrifuged at $3000 \mathrm{rpm}$ for $3 \mathrm{~min}$ and the supernatant was discarded. Afterward, remaining conidial pellet were re-suspended with sterile distilled water. The conidial suspension was adjusted to a concentration of $5 \times 10^{5}$ conidia per $\mathrm{ml}$ with an aid of haemocytometer. Following inoculation, plants were covered with polyethylene and incubated at $26^{\circ} \mathrm{C}$ for 24 hours. Later, polyethylene was removed and rice plants were kept for 6 days at $70 \%$ relative humidity $(\mathrm{RH})$. Non inoculated plants sprayed with sterile distilled water served as the control.

\section{The effect of temperature and leaf wetness duration on disease severity}

The trial was established to search the effect of temperature and leaf wetness duration on blast infection on both Edirne and Osmancik-97 inoculated with $P$. oryzae in a climatic chamber set from 20 to $32^{\circ} \mathrm{C}$ temperature, $70 \%$ humidity, $12 \mathrm{~h}$ fluorescent light and $12 \mathrm{~h}$ dark. The experiment included five wetness duration $(6,12,18,24$ and $30 \mathrm{~h})$ for infection and four temperatures $\left(20,24,28\right.$ and $\left.32^{\circ} \mathrm{C}\right)$ for advance of disease. In the trial, 100 rice plants were used for each combination of temperature and leaf wetness duration and the experiment was repeated twice. This trial was arranged as a split plot design with two replications, using plants of cvs. Edirne and Osmancik-97 inoculated with a suspension of $5 \times 10^{5}$ conidia per $\mathrm{ml}$ of $P$. oryzae by spraying plants with a hand held sprayer. Sterile distilled water was similarly applied on control plants. After all treatment period, rice plants were removed to another climatic chamber with $26^{\circ} \mathrm{C}$ temperature and a relative humidity of $70 \%$. All inoculated and control rice plants were kept in a controlled climatic chamber as described above (Fig. 1).

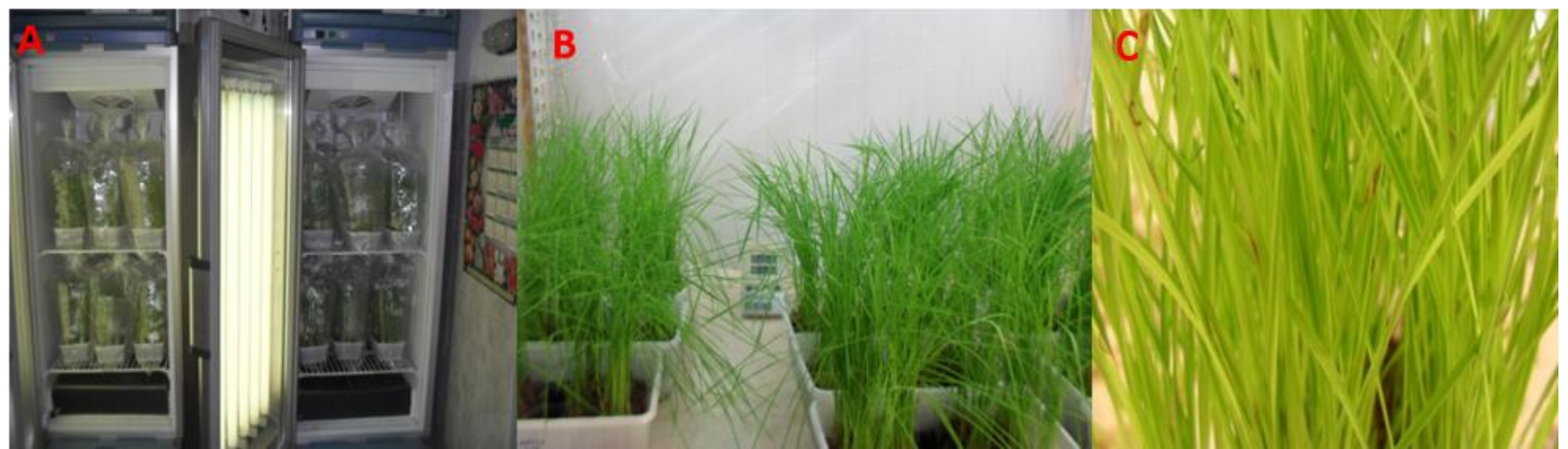

Figure 1. Incubation period of plants after inoculation (A, B) and the period of disease severity assessment (C) Şekil 1. Inokulasyon sonrası bitkilerin inkübasyon dönemi $(A, B)$ ve hastalık şiddeti değerlendirme dönemi $(C)$ 
Disease evaluation on the individual of rice seedlings was performed on a scale (Anonymous, 1996) of 0 to 9 $(0=$ non affected; $1=1 \%$ affected leaf area; $3=10 \%$ affected leaf area; $5=25 \%$ affected leaf area; $7=50 \%$ affected leaf area; $9=$ more than $50 \%$ affected leaf area) seven days after inoculation. Percent disease severity was calculated using the Townsend-Heuberger formula (Townsend and Heuberger, 1943).

\section{Sporulation induction of Pyricularia oryzae}

$P$. oryzae often produces small amounts of conidia when grown in artificial growing medium. In order to obtain more sporulation, $P$. oryzae Ceyhan isolate PC1 was grown up at $27^{\circ} \mathrm{C}$ and under UV-light at $12 \mathrm{~h}$ day/night cycle for 21 days. Afterward, mycelial discs cut about $1 \mathrm{~cm}$ width and $5 \mathrm{~cm}$ long like bands were transferred into another petri dishes no including PDA medium. All cultures were incubated at $27^{\circ} \mathrm{C}$ under UV-light at $12 \mathrm{~h}$ day/night cycle during about 3-4 days.

\section{Statistical analysis}

Statistical analysis of the data was realized using the
SPSS statistics program (version 11.5, SPSS Inc., Chicago, IL, USA). Analysis of variance was performed at the significance level of $P=0.05$. When appropriate, means were separated using Duncan's Multiple Range Test $(P=0.05)$.

\section{RESULTS and DISCUSSION}

The effect of temperature and leaf wetness duration on disease severity

At the end of the incubation period, while disease progress occurred in all stages of the trial, there was no symptom of blast disease in the uninoculated control plants. The impact of wetness duration and temperature on the blast severity (\%) on cvs. Osmancik-97 and Edirne changed from 0.1 to 12.3. While the lowest disease severity (\%) on Edirne and Osmancik-97 varieties were 1 and 0,1 at $20^{\circ} \mathrm{C}$ temperature and 6-hour leaf wetness, the highest disease severity (\%) values were 12.3 and 4.0 at $28^{\circ} \mathrm{C}$ temperature and 30-hour leaf wetness, respectively (Table 1).

Table1. The mean blast severity on cvs. Edirne and Osmancık-97 inoculated with $P$. oryzae at different temperatures and leaf wetness durations

Cizelge 1. P. oryzae'nın farklı sıcaklık ve yaprak ıslaklık sürelerinde çeşitler üzerindeki ortalama hastalık şiddeti

\begin{tabular}{lllllll}
\hline Cultivar & Duration(h) & \multicolumn{2}{l}{ Temperature $\left({ }^{\circ} \mathrm{C}\right)$} & Average(\%) \\
\cline { 3 - 6 } & & 20 & 24 & 28 & 32 & \\
Edirne & 6 & $1.0 \pm 0.34$ & $3.3 \pm 0.45$ & $6.2 \pm 0.45$ & $6.8 \pm 0.78$ & 4.3 \\
& 12 & $3.0 \pm 0.34$ & $4.9 \pm 0.23$ & $7.2 \pm 0.56$ & $7.6 \pm 0.45$ & 5.7 \\
& 18 & $4.7 \pm 0.89$ & $6.3 \pm 0.78$ & $9.9 \pm 0.34$ & $8.3 \pm 0.33$ & 7.3 \\
& 24 & $5.4 \pm 0.56$ & $8.1 \pm 0.34$ & $11.8 \pm 0.23$ & $9.3 \pm 0.22$ & 8.7 \\
\hline Average & 30 & $6.6 \pm 0.33$ & $8.7 \pm 0.45$ & $12.3 \pm 0.78$ & $9.8 \pm 0.00$ & 9.4 \\
\hline \multirow{2}{*}{ Osmanclk-97 } & 6 & 4.1 & 6.3 & 9.5 & 8.7 & $7.1 \mathrm{a}$ \\
& 12 & $0.1 \pm 0.11$ & $1.0 \pm 0.12$ & $2.2 \pm 0.45$ & $2.3 \pm 0.11$ & 1.4 \\
& 18 & $0.9 \pm 0.23$ & $1.6 \pm 0.22$ & $2.7 \pm 0.22$ & $2.7 \pm 0.00$ & 2.0 \\
& 24 & $1.3 \pm 0.22$ & $1.9 \pm 0.12$ & $3.1 \pm 0.23$ & $2.8 \pm 0.34$ & 2.3 \\
\hline Avarage & 30 & $1.8 \pm 0.23$ & $2.4 \pm 0.00$ & $3.4 \pm 0.11$ & $3.0 \pm 0.34$ & 2.7 \\
\hline General Average & & $2.2 \pm 0.22$ & $2.7 \pm 0.45$ & $4.0 \pm 0.23$ & $3.4 \pm 0.11$ & 3.1 \\
\hline
\end{tabular}

Values with in the same letter are not significantly different according to Duncan Multiple Range Test $(P=0.05)$.

The current epidemiological study conducted in a controlled environment has demonstrated the efficacy of wetness duration, temperature and cultivars on the progress of rice blast disease. The results of many studies revealed a significant relationship among leaf wetness duration, temperature, and disease severity (MacHardy et al., 1989; Trapero-Casas and Kaiser, 1992; Webb and Nutter, 1997; Uysal and Kurt, 2017). The increase or decrease in disease severity values for different cultivars are most likely due to the susceptibility of cultivars to the blast disease. Miah et al. (2017) explained that resistant cultivars against rice blast disease in compare to susceptible cultivars indicates different degrees of resistance.
Blast severity increased as temperature and leaf wetness durations increased on cvs. Edirne and Osmancık-97. The highest disease severity (\%) values were recorded as 12.3 and 4.0 respectively, while the temperature was $28^{\circ} \mathrm{C}$ and the duration of leaf wetness was 30 hours (Table1). Although the disease severity increased with increasing leaf wetness at all temperatures, the disease severity $(\%)$ value of $32^{\circ} \mathrm{C}$ was lower than $28^{\circ} \mathrm{C}$ at 18 -hour leaf wetness duration. Minimum 6-hour leaf wetness duration at $20^{\circ} \mathrm{C}$ was sufficient to the beginning of the rice blast infection for Edirne and Osmancik-97. Disease severity values on Edirne were higher than Osmancik-97 for the same wetness duration and temperature. Studies on the 
factors such as temperature, humidity, light intensity and their effects on mycelial development and sporulation of $P$. oryzae were revealed that the optimal temperature for mycelial growth is about $28^{\circ} \mathrm{C}$ and the growth ranged from $8-9^{\circ} \mathrm{C}$ to $37^{\circ} \mathrm{C}$ (Suematsu, 1916; Sawada, 1927; Nisikado, 1927; Abe, 1930; Yoshii, 1936; Ou, 1985), but, optimum growth temperatures can vary from isolate to isolate (Konishi, 1933; Tochinai and Shimamura, 1932; Tseng et al., 1965; Ou, 1985).
Temperature $(\mathrm{P} \leq 0.05)$ and leaf wetness duration $(\mathrm{P} \geq$ 0.05) had a major impact on conidial germination, appressorium formation, penetration, rice blast disease development and severity (Figure 2 and 3 ). Knowledge about the effect of temperature and leaf wetness duration on disease severity on different varieties is vital to assessing the epidemiology of rice blast disease.

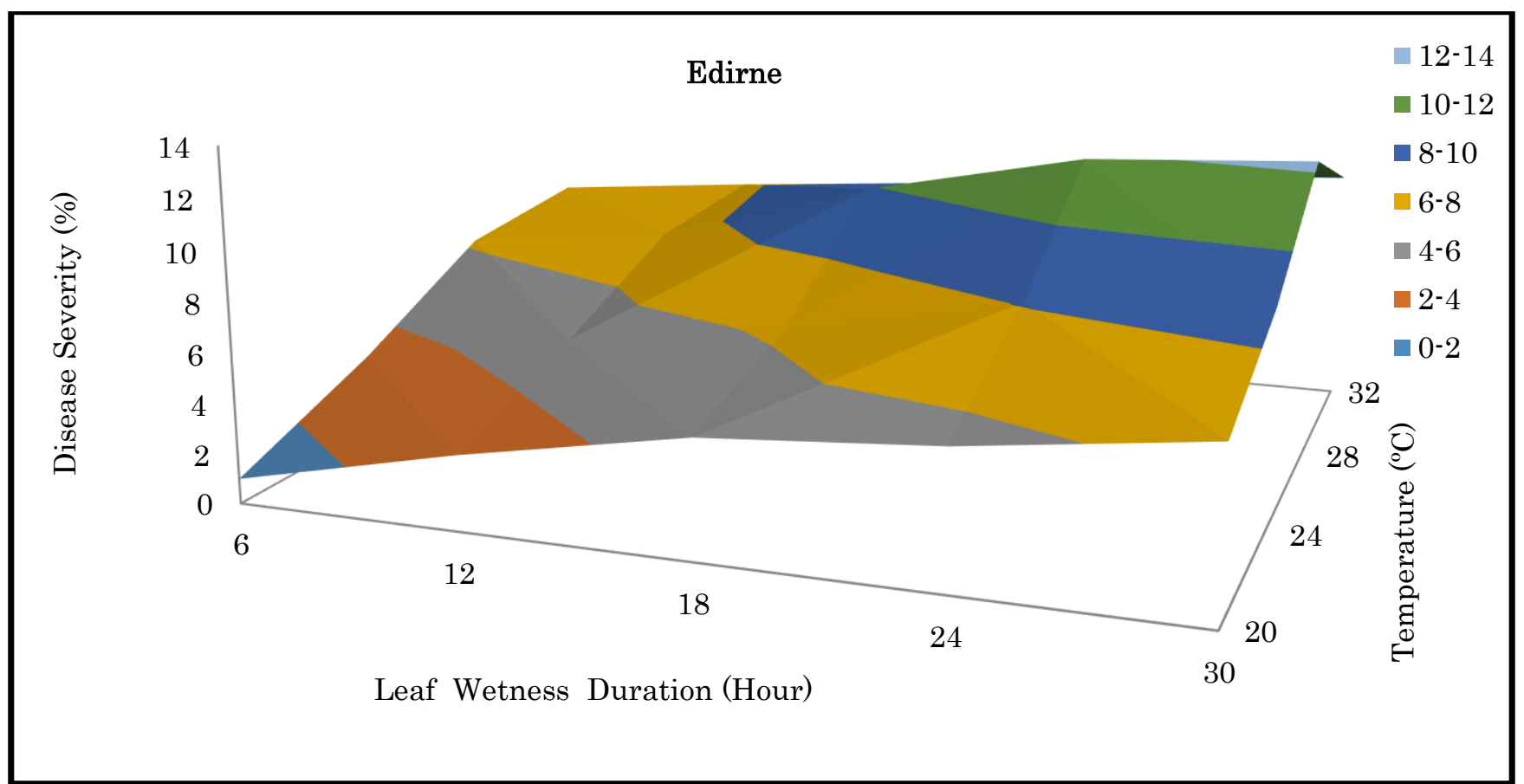

Figure 2. The effects of different temperatures and leaf wetness durations on blast severity in cv. Edirne Şekil 2. Edirne çeşidinde farklı sıcaklık ve yaprak 1 slaklık sürelerinin hastalık şiddeti üzerine etkisi

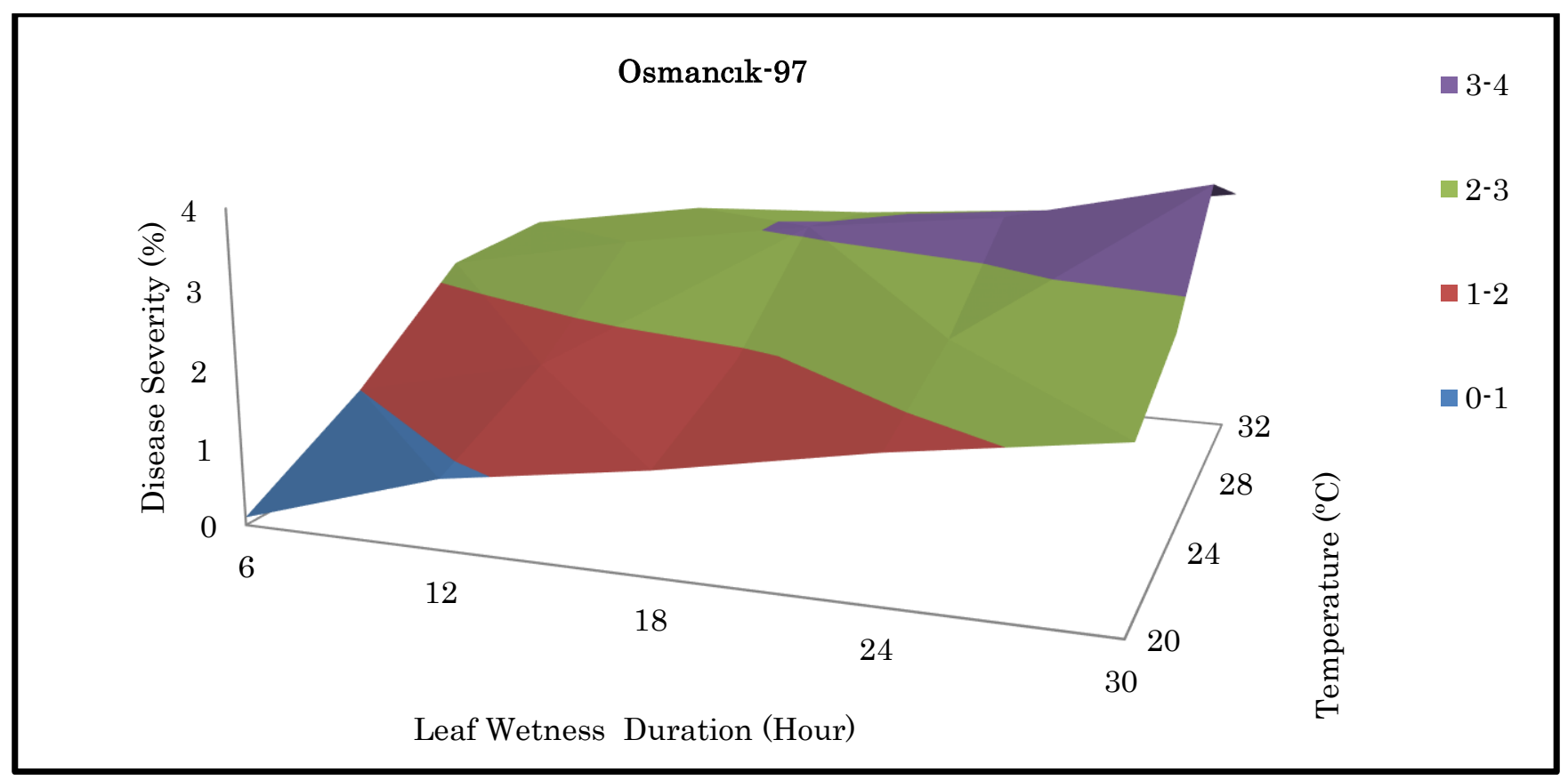

Figure 3. The effects of different temperatures and leaf wetness durations on blast severity in cv. Osmanclk-97 Şekil 3. Osmancık-97 çeşidinde farklı sıcaklık ve yaprak ıslaklık sürelerinin hastalık şiddeti üzerine etkisi 
Kato (1974) reported that conidial germination of $P$. oryzae can occur in the water within 3 hours. In addition, Rajput et al. (2017) revealed that the highest spore germination and appressoria formation rates occurred within 4 hours at 22,27 and $32^{\circ} \mathrm{C}$.

Rice plants leaves were infected and caused symptoms in all combinations of temperatures and leaf wetness durations by $P$. oryzae isolate $\mathrm{PC} 1$. When the effects of temperature and leaf wetness duration interaction on the mean disease severity (\%) were compared with Duncan's Multiple Comparison Test (Table 2), the lowest mean disease severity (\%) value was 2.7 at $20^{\circ} \mathrm{C}$ in different leaf wetness durations. The highest mean disease severity (\%) value was found as 6.3 , while the temperature was $28^{\circ} \mathrm{C}$ indifferent leaf wetness duration. Recent research on the effect of temperature on the incidence of the rice blast pathogen Magnaporthe oryzae indicated that the infection stages of pathogen such as conidial germination, appressoria formation, penetration and disease development were influenced significantly from temperature. They also reported that the maximum spore germination was observed at $27^{\circ} \mathrm{C}$ temperature, the spore germination decreased at $22^{\circ} \mathrm{C}$ and minimum spore germination was observed at $32^{\circ} \mathrm{C}$ (Rajput et al., 2017). These findings indicated that spore germination was inhibited with higher temperature. The temperature rise can inhibit the MgNIMA gene, which encodes the kinase protein that is a key factor for mitosis. As a result of blocking of mitosis, conidia loses vitality (Liu et al., 2007).

Table2. The effects of interaction between temperatures and leaf wetness durations on the mean blast severity Cizelge 2. Sicaklık ve yaprak ıslaklık süresi interaksiyonunun ortalama hastalık şiddeti üzerine etkisi

\begin{tabular}{|c|c|c|c|c|c|}
\hline Duration (h) & \multicolumn{4}{|c|}{ Temperature $\left({ }^{\circ} \mathrm{C}\right)$} & \multirow[t]{2}{*}{ Average (\%) } \\
\hline & 20 & 24 & 28 & 32 & \\
\hline 6 & $0.6 \pm 0.291$ & $2.2 \pm 0.70 \mathrm{j}$ & $4.2 \pm 1.18 \mathrm{f}$ & $4.6 \pm 1.32 \mathrm{ef}$ & $2.9 \mathrm{~d}$ \\
\hline 12 & $2.0 \pm 0.63 \mathrm{k}$ & $3.3 \pm 0.97 \mathrm{hl}$ & $5.0 \pm 1.34 \mathrm{e}$ & $5.2 \pm 1.42 \mathrm{de}$ & $3.8 \mathrm{c}$ \\
\hline 18 & $3.0 \pm 1.031$ & $4.1 \pm 1.32 \mathrm{fg}$ & $6.5 \pm 1.96 \mathrm{c}$ & $5.6 \pm 1.62 \mathrm{~d}$ & $4.8 \mathrm{~b}$ \\
\hline 24 & $3.6 \pm 1.13 \mathrm{gh}$ & $5.3 \pm 1.64 \mathrm{de}$ & $7.6 \pm 2.41 \mathrm{~b}$ & $6.2 \pm 1.84 \mathrm{c}$ & $5.7 \mathrm{a}$ \\
\hline 30 & $4.4 \pm 1.26 \mathrm{f}$ & $5.7 \pm 1.75 \mathrm{~d}$ & $8.2 \pm 2.43 \mathrm{a}$ & $6.6 \pm 1.83 \mathrm{c}$ & $6.2 \mathrm{a}$ \\
\hline Average (\%) & $2.7 \mathrm{~d}$ & $4.1 \mathrm{c}$ & $6.3 \mathrm{a}$ & $5.6 \mathrm{~b}$ & \\
\hline
\end{tabular}

Values within the same letter are not significantly different according to Duncan Multiple Range Test (P=0.05).

Considering different leaf wetness durations, the lowest mean disease severity (\%) was recorded as an average of 2.9 in 6 -hour leaf wetness. On the other hand, the highest mean disease severity (\%) was obtained as an average of 6.2 in 30-hour leaf wetness. Rowlandson (2015) reported that studies have been carried out for centuries on the relationship between leaf wetness duration and the development of fungal diseases. However, it is known that as the wetness duration increases, the rice blast severity increases (Kato,1976). Our data are consistent with the findings of Teng (1994), who reported that the sporulation of $M$. oryzae and disease progress was supported by high humidity $(89 \%)$, optimum temperature $\left(25-28^{\circ} \mathrm{C}\right)$, and minimal 4 hour leaf wetness.

Considering the interactions between temperature and leaf wetness, the lowest mean blast severity (\%) was observed in 6 hours of leaf wetness and an average value of 0.6 at $20^{\circ} \mathrm{C}$.

The highest mean disease severity (\%) was observed with an average value of 8.2 at 28 -hour leaf wetness duration and $30^{\circ} \mathrm{C}$ temperature. According to the statistical analysis mean disease severity (\%) values at the end of the leaf wetness period of 24 and 30 hours at $32^{\circ} \mathrm{C}$ temperature appeared in the same group both in itself and 18-hour leaf wetness duration at $28^{\circ} \mathrm{C}$ temperature. There were significant interactions between the temperature and leaf wetness durations. Anderson et al. (1947) whose are studying about infectivity, spreading and continuity of $P$. oryzae reported that it was required to have 16-24 hours of continuous leaf wetness at $24-28^{\circ} \mathrm{C}$ to produce the most infection on the rice plant.

\section{Sporulation inducing of Pyricularia oryzae}

With this technique developed in studies on the epidemiology and control measurements of rice blast caused by (Pyricularia oryzae Cav.) in Çukurova, it has become quite easy to increase fungal spore production in artificial culture medium (Figure 4 and 5).

\section{CONCLUSION}

The current study indicated the impact of leaf wetness duration and temperature on the beginning, progress, infection severity of the rice blast disease at two rice cultivars and also described a simple and effective technique to increase spore density in artificial culture medium. Disease severity was increased by the rising temperature and leaf wetness on Edirne and Osmancık-97 cultivars and the highest disease severity (\%) values were recorded at the $28^{\circ} \mathrm{C}$ temperature and 30-hour leaf wetness duration. 4hour leaf wetness duration at $20^{\circ} \mathrm{C}$ was sufficient for 
the disease to occur. This information will contribute to the disease forecasting, management, the production of abundant spore for using in artificial inoculation and for testing of resistant and susceptible genotypes in controlled environment.

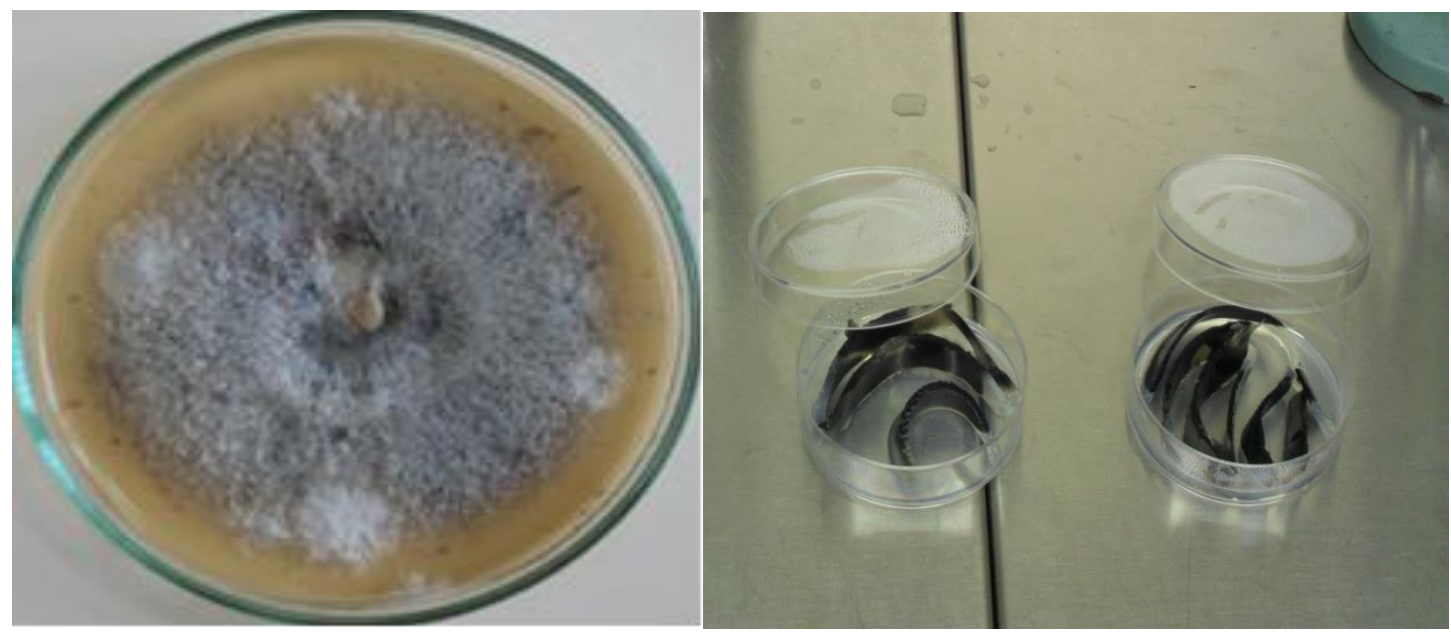

Figure 4.Increased spore density in PDA growing medium Şekil 4 PDA kültür ortamında artan spor yoğunluğu

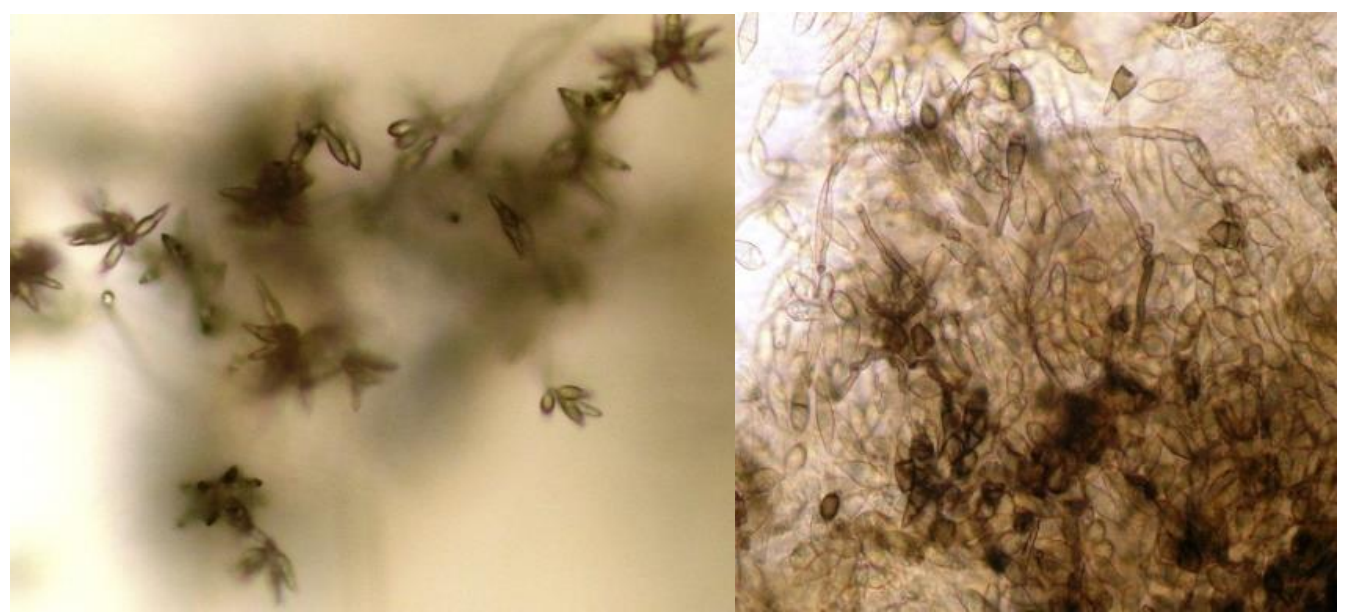

Figure 5. Spore density after treatment on culture medium Şekil 5. Kültür ortamında uygulama sonrası spor yoğunluğu

\section{ACKNOWLEDGEMENTS}

The project was supported by the Republic of Turkey Ministry of Agriculture and Forestry, General Directorate of Agricultural Research and Policies (Project no. TAGEM-BS-10 / 07-04 / 02-11) and Hatay Mustafa Kemal University Scientific Research Projects Unit (Project no. 1101 D 0102). We are thankful to them.

\section{Author's Contributions}

The contribution of the authors is equal.

\section{Statement of Conflict of Interest}

Authors have declared no conflict of interest

\section{REFERENCES}

Abe $\mathrm{T}$ 1930. The relation of temperature and time to the invasion of rice blast fungus. Annals of the
Phytopathological Society of Japan 2: 277-278.

Anderson AL, Henry BW, Tullis EC 1947. Factors affecting infectivity, spread and persistence of Pyricularia oryzae Cav. Ibid 37: 94-110.

Anonymous 1996. Zirai mücadele standart ilaç deneme metotları. Tarım ve Köyişleri Bakanlığı Cilt II: 1821.

Anonymous 2020. Bitki koruma ürünleri veritabanı Tarım ve Orman Bakanlığı. https://bku.tarimorman.gov.tr/Arama/Index [Accessed on December 2020].

Aravindan S, Yadav MK, Sharma P 2016. Biological control of rice blast disease with Trichoderma spp. under upland rice system. ORYZA-An International Journal on Rice 53(2): 167-173.

Asibi AE, Qiang Chai QC, Coulter JA 2019. Rice blast: A disease with implications for global food security. Agronomy 9: 451.

Bonman JM, Vergel De Dios TI, Bandong JM, Lee EJ 
1992. Breeding rice for resistance to pests. Annu. Rev. Phytopathology 30: 507-528.

Castroagudín VL, Moreira SI, Pereira DAS, Moreira SS, Brunner PC, Maciel JLN, Crous PW, McDonald BA, Ceresini PC 2016. Pyriculari agraminis-tritici, a new Pyricularia species causing wheat blast. persoonia. Molecular Phylogeny and Evolution of Fungi 37: 199-216.

Chen WC, Chiou TY, Delgado AL, Liao CS 2019. The control of rice blast disease by the novel biofungicide formulations. Sustainability 11: 3449.

Diéguez-Uribeondo J, Förster H, Adaskaveg JE 2011. Effect of wetness duration and temperature on the development of anthracnose on selected almond tissues and comparison of cultivar susceptibility. Phytopathology 101: 1013-1020.

FAO 2009. FAO's director general on how to feed the world in 2050. Insights from an Expert Meeting at FAO 1: 1-35.

FAO 2018. Food and Agriculture Organization, Databases. Rice Market Monitor. http://www.fao.org/3/I9243EN/i9243en.pdf

[Accessed on March 2020]

FAO 2020. World food situation. http://www.fao.org/worldfoodsituation/csdb.

Godfray HCJ, Beddington JR, Crute IR, Haddad L, Lawrence D, Muir JF, Pretty J,Robinson S, Thomas SM, Toulmin C 2010. Food security: The challenge of feeding 9 billion people. Science 327: 812-818.

Gohel HL, Chauhan HL, 2015. Integrated management of leaf and neck blast disease of rice caused by Pyricularia oryzae. Afr. J. Agric. Res. 10: 2038-2040.

Groth DE 2006. Azoxystrobin rate and timing effects on rice head blast incidence and rice grain and milling yields. Plant Disease 90:1055-1058.

Kato H 1974. Epidemiology of rice blast disease. Rev. Plant Prot. Res. 7:1-20.

Kato H 1976. Some topics in disease cycle of rice blast and climatic factors. In Climate and Rice. International Rice Research Institute, Manila, Philippines, pp. 417-425.

Khush GS, Jena KK 2009. Current status and future prospects for research on blast resistance in rice (Oryza sativa L.) in: Wang GL, Valent B, editors. Advances in genetics, genomics and control of rice blast disease. Springer, pp. 1-10.

Kongcharoen N, Nipon Kaewsalong N, Dethoup T 2020. Efficacy of fungicides in controlling rice blast and dirty panicle diseases in Thailand. Scientific Reports 10:16233.

Konishi S 1933. On the physiologic specialization in the rice blast fungus, Piricularia oryzae Br.et Cav. Forsch. auf dem Geb. Der Pflanzenkrankh.,Kyoto 2: 55-57.

Liu XH, Jian Ping L, Lei Z, Bo D, Hang M, Lin F 2007. Involvement of a Magnaporthe grisea serine/threonine kinase gene, MgATG1, in appressorium turgor and pathogenesis. Eukaryotic Cell 6: 997-1005.

MacHardy WE, Gadoury DM 1989. A revision of Mill's criteria for predicting apple scab infection periods. Phytopathology 79:304-310.

Miah G, Rafii MY, Ismail MR, Sahebi M, Hashemi FSG, Yusuff O, Usman MG 2017. Blast disease intimidation towards rice cultivation: A review of pathogen and strategies to control. The Journal of Animal \& Plant Sciences 27(4): 1058-1066.

Nalley L, Tsiboe F, Durand Morat A, Shew A, Thoma G 2016. Economic and environmental impact of rice blast pathogen (Magnaporthe oryzae) alleviation in the United States. Plosone 11(12): e0167295. doi:10.1371/journal.pone.0167295.

Nisikado Y 1927. Studies on rice blast disease. Japanese Journal of Botany 3: 239-244.

Oran YK 1975. Güneydoğu Anadolu'da çeltik Yanıklığı fungusu (Pyricularia oryzae)' nun taksonomisi, bioekolojisi, zararı ve çeltik çeşitlerinin dayanıklılığı üzerine araştırmalar. Bitki Koruma Bülteni 6(1): 1-46.

Ou SH, 1985. Blast. in: Ou, SH. (ed) Rice diseases. 2nd edn. Wallingford, UK, CAB International, pp. 109201.

Rajput LS, Sharma T, Madhusudhan P, Sinha P 2017. Effect of temperature on rice blast infection process with emphasis on appressoria formation by Magnaporthe oryzae. International Journal of Current Microbiology and Applied Sciences 6(4): 1931-1939.

Rowlandson T, Gleason M, Sentelhas P, Gillespie T, Thomas C, Hornbuckle B 2015. Reconsidering leaf wetness duration determination for plant disease management. Plant Disease 99(3): 310-315.

Sawada K 1927. Lecture on the rice blast disease. Bulletin of the Goverment Research Institute, Department of Agriculture Formosa 45:88.

Singh HS, Kaushik SS, Chauhan MS, Negi RS 2019. Efficacy of different fungicides against rice blast caused by Pyricularia oryzae (Cav.) under field condition in Satna district of Madhya Pradesh. International Journal of Current Microbiology and Applied Sciences 8(6): 63-69.

Sirithunya P, Sreewongchai T, Sriprakhon S, Toojinda T, Pimpisithavorn S, Kosawang C, Smitamana P 2007. Assessment of genetic diversity in Thai isolates of Pyricularia grisea by random amplification of polymorphic DNA. Journal of Phytopathology 156: 196-204.

Skamnioti P, Gurr SJ 2009. Against the grain: safeguarding rice from rice blast disease. Trends in Biotechnology 27:141-150.

Suematsu N 1916. On the artificial culture of rice blast fungus (Dactylaria parasitans Cav.). Botanical Magazine 30:97-99.

Suzuki H 1975. Meteorological factors in the epidemiology of rice blast. Annual Review of 
Phytopathology 13: 239-56.

Talbot NJ 2003. On the trail of a cereal killer: exploring the biology of Magnaporthe grisea. Annual Review of Microbiology 57: 177-202.

Teng PS 1994. The epidemiological basis for blast management. In: rice blast disease. R. S. Zeigler and S. A. Leong, eds. CAB International, Wallingford, U.K.

Trapero-Casas A, Kaiser WJ 1992. Development of Didymella rabiei the teleomorph of Ascochyta rabiei, on chickpea straw. Phytopathology 82(11): 1261-1266.

Tseng TC, Yuan CS, Wu LC 1965. Temperature response of Piricularia oryzae Cav. isolated in different sesasons in Taiwan. Botanical Bulletin of Academia Sinica 6: 93-100.

Tochinai Y, Shimamuru M 1932. Studies on the physiologic specialization in Piricularia oryzae Br. et Cav. Annals of the Phytopathological Society of Japan 2: 414-441.

Townsend GK, Heuberger JW 1943. Methods for estimating losses caused by diseases in fungicide experiments. Plant Disease Report 27: 340-343.
TUIK 2018. Turkish statistical institute Crop Production Statistics. http://www.tuik.gov.tr [Accessed on March 2020].

Uysal A, Kurt \$̧ 2017. Influence of inoculums density, temperature, wetness duration and leafage on infection and development of spinach anthracnose caused by the fungal pathogen Colletotrichum spinaciae. Eur J Plant Pathol. DOI 10.1007/s10658017-1249.

Yoshii H 1936. Pathological studies of rice blast caused by Piricularia oryzae. I. some studies on the physiology of the pathojen. II. the mode of infection of the pathogen. Annals of the Phytopathological Society of Japan 6: 199-218.

Webb DH, Nutter FW 1997. Effects of leaf wetness duration and temperature on infection efficiency, latent period, and rate of pustule appearance of rust in alfalfa. Phytopathology 87: 946-950.

Zhou E, Jia Y, Singh P, Correll J, Lee F 2007. Instability of the Magnaporthe oryzae a virulence gene AVR-pita alters virulence. Fungal Genet. Biol. 44: 1024-1034. doi: 10.1016/j.fgb.2007.02.003 PMID:17387027. 